\title{
PARTIAL DEAFNESS TREATMENT IN CHILDREN: EDUCATIONAL SETTINGS AFTER 5 TO 7 YEARS OF COCHLEAR IMPLANT USE
}

\author{
Malgorzata Zgoda ${ }^{1,2}$, Artur Lorens ${ }^{1,2}$, Henryk Skarzynski ${ }^{1,2}$ \\ ${ }^{1}$ Institute of Physiology and Pathology of Hearing, Zgrupowania AK "Kampinos" 1, 01-943 Warsaw, Poland \\ ${ }^{2}$ World Hearing Center, Mokra 17, Kajetany, 05-830 Nadarzyn, Poland
}

Corresponding author: Malgorzata Zgoda, Institute of Physiology and Pathology of Hearing, ul. Zgrupowania AK “Kampinos” 1, 01-943 Warszawa, Poland, e-mail: m.zgoda@ifps.org.pl

\begin{abstract}
Background: Cochlear implant (CI) eligibility criteria have broadened to include individuals with partial deafness (PD), a condition in which prior to implantation a significant amount of low frequency hearing remains. Partial Deafness Treatment (PDT) with cochlear implants, gives the patient the ability to perceive high frequency sounds to complement low frequency acoustic hearing. There is a lack of information concerning the educational status of children after PDT. This study reports the demographics, speech perception abilities, and educational setting of PD children before cochlear implantation and 5 to 7 years later.

Material and methods: The study group consisted of 18 children who had undergone cochlear implantation using the round window hearing preservation procedure. The average time of device use in the group was 5.9 years (range 5.1-7.4 years). The average age at implantation was 9.9 years (range 4.1-15.0 years). A retrospective review of patient charts was done. Their previous and current school setting was assessed with a survey distributed to the parents of these children.

Results: Prior to implantation, $89 \%$ of children were being educated in mainstream schools and $11 \%$ were attending schools for the deaf and hard of hearing. After 5 to 7 years of implant use, the percentage of children in a mainstream setting was $83 \%$ and $17 \%$ were in special education.

Conclusions: Successfully inclusion of hearing impaired children into the mainstream education system is one of the major goals of cochlear implantation. Although the study group was small, it appears that children after PDT, whose speech perception substantially improves after cochlear implantation, may continue their education in a mainstream setting.
\end{abstract}

Key words: partial deafness treatment $\bullet$ cochlear implant $\bullet$ children

\section{TRATAMIENTO DE LA SORDERA PARCIAL EN LOS NIÑOS: EL CONTEXTO EDUCATIVO DESPUÉS DE 5 A 7 AÑOS DE USO DE UN IC}

\section{Resumen}

Antecedentes: Los criterios de elegibilidad para los implantes cocleares (IC) se han ampliado para incluir a personas con sordera parcial (PD), una condición en la, que antes de la implantación, sigue existiendo un nivel significativo de la audición a baja frecuencia. El tratamiento de la sordera parcial (PDT) con implantes cocleares le da al paciente la capacidad de percibir sonidos de alta frecuencia para complementar la audición acústica a baja frecuencia. Hay una falta de información sobre la situación educativa de los niños después del PDT. Este estudio presenta los datos demográficos, las habilidades de percepción del habla y el contexto educativo de los niños con la sordera parcial antes de la implantación coclear y de 5 a 7 años después de realizarla.

Materiales y métodos: Se analizó un grupo de 18 niños que habían sido sometidos a un implante coclear utilizando el procedimiento de conservación de la audición de la ventana redonda. El tiempo promedio de uso del dispositivo en el grupo era de 5.9 años (entre 5.1-7.4 años). La edad media al realizar el implante fue de 9.9 años (entre 4.1-15.0 años). Se llevó a cabo una revisión retrospectiva de las historias clínicas de los pacientes. Su contexto escolar anterior y actual se evaluó con una encuesta distribuida a los padres de los niños.

Resultados: Antes de la implantación, el 89\% de los niños estaban siendo educados en las escuelas normales y el 11\% asistían a escuelas para personas sordas y hipoacústicas. Después de 5 a 7 años de uso del implante, el porcentaje de niños en los centros ordinarios fue del $83 \%$ y del $17 \%$ en centros de educación especial.

Conclusiones: La inclusión con éxito de niños con discapacidad auditiva en el sistema general de educación es uno de los principales objetivos de la implantación coclear. Aunque el grupo de estudio fue reducido, parece que los niños después del tratamiento PDT, cuya percepción del habla mejora sustancialmente después de la implantación coclear, pueden continuar su educación en los centros ordinarios.

Palabras clave: tratamiento de sordera parcial $\bullet$ implante coclear • niños 


\title{
TRAITEMENT DE SURDITÉ PARTIELLE CHEZ LES ENFANTS: DISPOSITIFS ÉDUCATIFS APRÈS 5 À 7 ANS D'UTILISATION D'IMPLANT COCHLÉAIRE
}

\begin{abstract}
Abstrait
Contexte: Les critères d’éligibilité aux implants cochléaires se sont élargis pour inclure les personnes atteintes de surdité partielle, un état préalable à l'implantation dans lequel subsiste un nombre important de basse fréquence audible. Le traitement surdité partielle avec des implants cochléaires, donne au patient la capacité de percevoir les sons de haute fréquence pour compléter l’audition de basse fréquence. Il existe un manque d'informations concernant le statut éducatif des enfants après le traitement partiel de la surdité. Cette étude rapporte les données démographiques, les capacités de perception de la parole, et les dispositions éducatives des enfants atteints de surdité partielle avant implantation cochléaire et de 5 à 7 ans après l'implantation cochléaire.

Matériel et méthodes: Le groupe d'étude se composait de 18 enfants qui avaient subi une implantation cochléaire utilisant la méthode de préservation de l'audition de la fenêtre ronde. Le temps moyen de l'utilisation des implants dans le groupe était de 5,9 ans (fourchette allant de 5.1 à 7.4 ans). Lâge moyen lors de l'implantation était de 9,9 ans (fourchette allant de 4.1 à 15.0 ans). Une étude rétrospective des dossiers des patients a été faite. Leur milieu scolaire antérieur et actuel a été évalué par un sondage distribué aux parents de ces enfants.

Résultats: Avant l'implantation, $89 \%$ des enfants étaient scolarisés dans des écoles ordinaires et $11 \%$ dans des écoles pour sourds et malentendants. Après 5 à 7 ans d'utilisation d'implants, le pourcentage d'enfants intégrer dans le cycle scolaire normal était de $83 \%$ et $17 \%$ dans l’enseignement spécialisée.

Conclusions: Réussir l'intégration des enfants malentendants dans le système éducatif classique est l'un des principaux objectifs de l'implantation cochléaire. Bien que le groupe d'étude fût réduit, il apparaît que les enfants ayant bénéficiés du traitement de surdité partielle par implantation cochléaire dont la perception du discours s'est substantiellement améliorée après l'implantation, peuvent poursuivre leur scolarité dans le système éducatif classique.
\end{abstract}

Mots clés: traitement de surdité partielle • implant cochléaire • enfants

\section{ЛЕЧЕНИЕ ЧАСТИЧНОЙ ГЛУХОТЫ У ДЕТЕЙ: ОБСТАНОВКА ПРИ ОБУЧЕНИИ ПОСЛЕ 5-7 ЛЕТ ПРИМЕНЕНИЯ КОХЛЕАРНОГО ИМПЛАНТАТА}

\section{Краткий обзор}

История вопроса: Критерии отбора в аспекте применения кохлеарного имплантата (CI) были расширены с включением пациентов с частичной глухотой (PD), состоянием, при котором до имплантации сохраняется возможность слышать значительное количество низкочастотных звуков. Лечение частичной глухоты (PDT) с помощью кохлеарных имплантатов дает основу для восприятия высокочастотных звуков в дополнение к слышимости в диапазоне низких частот. На данный момент получено недостаточно информации относительно способностей к обучению у детей после лечения частичной глухоты. В настоящем исследовании получены сведения о демографических данных, способности к восприятию речи и обстановке при обучении детей с PD до установки кохлеарного имплантата и через 5-7 лет после нее.

Материалы и методы: Опытная группа состояла из 18 детей, которым был установлен кохлеарный имплантат с помощью процедуры сохранения слуха при воздействии на окно улитки. В среднем время применения устройства в группе составляло 5,9 лет (в пределах 5,1-7,4 лет). В среднем возраст при имплантации составлял 9,9 лет (в пределах 4,1-15,0 лет). Был проведен ретроспективный анализ историй болезней пациентов. Предыдущая и текущая школьная обстановка подлежала оценке при помощи опросников, выданных родителям детей.

Результаты: Перед проведением имплантации $89 \%$ детей проходили обучение в обычных школах, $11 \%$ детей посещали школы для глухих или слабослышащих. Через 5-7 лет после применения имплантата процентная доля детей, обучающихся в традиционном школьном окружении, составила $83 \%, 17 \%$ детей обучались в специализированых учебных заведениях.

Выводы: Успешное включение детей с ограничениями остроты слуха в традиционную систему образования является одной из основных целей применения кохлеарных имплантатов. Несмотря на небольшой размер опытной группы, можно предположить, что дети после лечения частичной глухоты, у которых проявляется улучшение восприятия речи после кохлеарной имплантации, могут продолжать образование в традиционном школьном окружении.

Ключевые слова: лечение частичной глухоты • кохлеарный имплантат • дети 


\section{Background}

The history of cochlear implants has reached another milestone in the last decade. The criteria for receiving the device have broadened, and patients with partial deafness (PD) have now been included as candidates for surgery $[1,2]$. After hearing preservation surgery using the round window approach was found safe for adults, it has now been found beneficial for children [2]. Since 2004, children with partial deafness can qualify for cochlear implant (CI) surgery. Partial Deafness Treatment (PDT) with cochlear implants, as proposed by Skarzynski at al., gives the patient the ability to perceive high frequency sounds to complement low frequency acoustic hearing [1].

The first PDT surgery on a child was a great challenge for the surgeons whose focus was to perform the operation with maximum hearing preservation. It was also an extremely hard decision for parents, who had to decide on behalf of a child who was not profoundly deaf and who was outside the then-current CI qualification criteria. At first, the aim of implanting a deaf child was to give them a chance to hear and an opportunity to develop verbal communication with their family [3]. With time and medical advances, we started to expect more. Technological achievements allowed many deaf children to access a mainstream education [4].

A major motivation for giving a child with $\mathrm{PD}$ an implant was to support its development of language and speech. In the case of PD, classical hearing aids are not as helpful as expected because high-frequency speech sounds are beyond their capabilities. Difficulties in communication can prevent children participating in a mainstream education. So allowing children to continue schooling in an open educational system was another important factor motivating surgery.

Worldwide there is a trend towards including handicapped children in the mainstream education system. It provides equality of education and also reduces costs [4]. Observations have shown the positive affect of PDT on a child's speech discrimination ability and their overall social functioning [5]. As there is a direct link between speech perception and the development of language, a child's speech perception is considered to be an important determinant of educational performance in mainstream classes. Recent studies show that cochlear implants are able to at least narrow the gap in performance between the hearing-impaired children and their hearing peers [6]. However, there is a lack of information concerning the educational status of children after PDT.

This study reports demographics, speech perception abilities, and educational settings of a group of children after PDT before cochlear implantation and 5 to 7 years after.

\section{Material and methods}

\section{Participants}

The study group consisted of 18 children, part of a larger group of children with PD who had undergone cochlear implantation using the round window hearing preservation

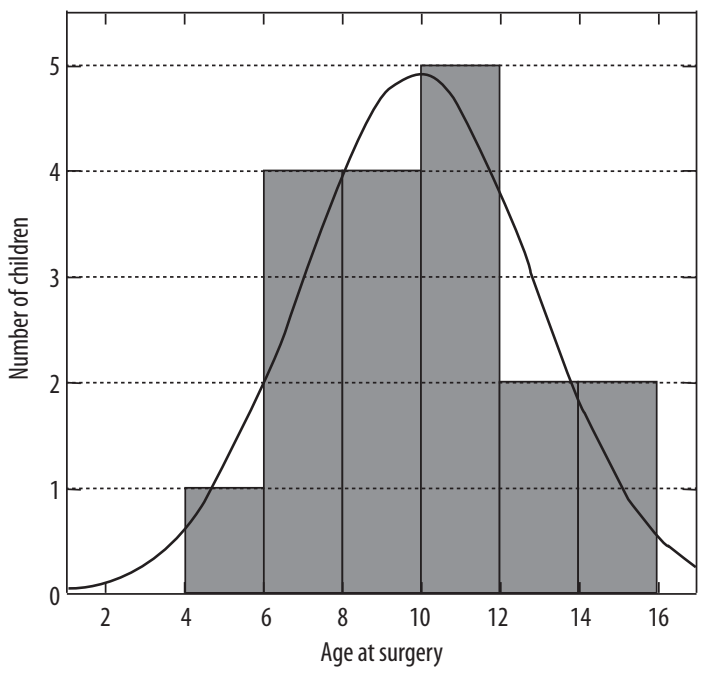

Figure 1. Distribution of age at time of implantation.

procedure. The 18 were chosen as having had the longest experience with CI, with the average being 5.9 years (range 5.1-7.4 years). As shown in Figure 1, the average age at cochlear implantation was 9.9 years (range 4.1-15.0 years). All children received a Med-El cochlear implant, either a Combi 40+ (4 subjects) or Pulsar (14 subjects). Average hearing thresholds measured before and 1 month after surgery are shown in Figure 2 for the implanted and the contralateral ear.

The reported aetiologies in the group were as follows: 12 unknown (including 7 children with no genetic screening and with negative screening towards $35 \mathrm{delG}$ ), perinatal asphyxia (5), and septicaemia (1). Additional disabilities were observed in 10 children (56\%), they included: vision impairment (7), vision impairment and epilepsy (1), vision impairment and delayed physical development (1), and delayed physical development (1).

All children, but one, were not screened for hearing problems after birth. Thus due to absence of hearing test results in earlier stages congenital hearing loss cannot be excluded. The diagnosis of hearing loss, as reported by parents, was done at 4 years of age on average (range 0.5-7 years) as shown in Figure 3. Two children from the study group have a healthy twin sibling.

All children were fitted bilaterally with hearing aids: 13 children immediately after diagnosis and 5 with a maximum delay of 2 years. Two children wear hearing aids occasionally.

\section{Methods}

Retrospective chart reviews of patients were done, demographic information was obtained, and data regarding audiological and speech perception tests was collected. Pure-tone audiometry was performed using a Siemens SD5 audiometer calibrated according to ANSI standards. Testing was done in an IAC soundproof booth using Sennheiser HDA 200 headphones. A standard clinical procedure was used for determining thresholds [7]. Speech perception 
Implanted ear (Hz)

$125250500750 \quad 100015002000300040006000$

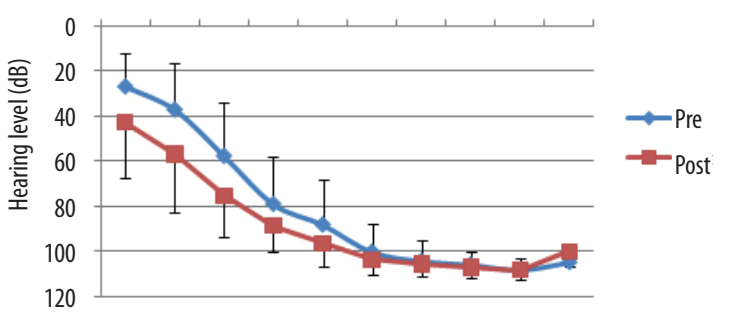

Controled ear (Hz)

125250500750100015002000300040006000

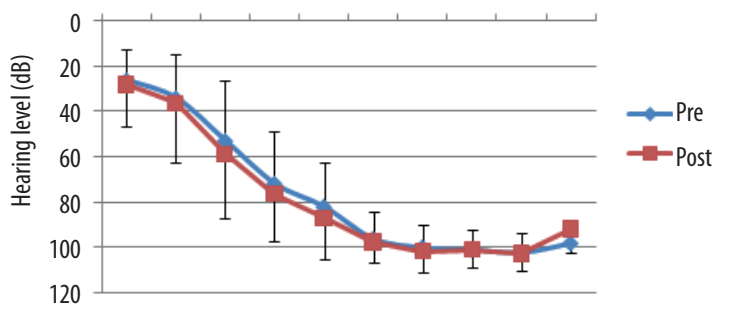

Figure 2. Average pure tone thresholds measured for the implanted and contralateral ear before, and 1 month after, surgery.

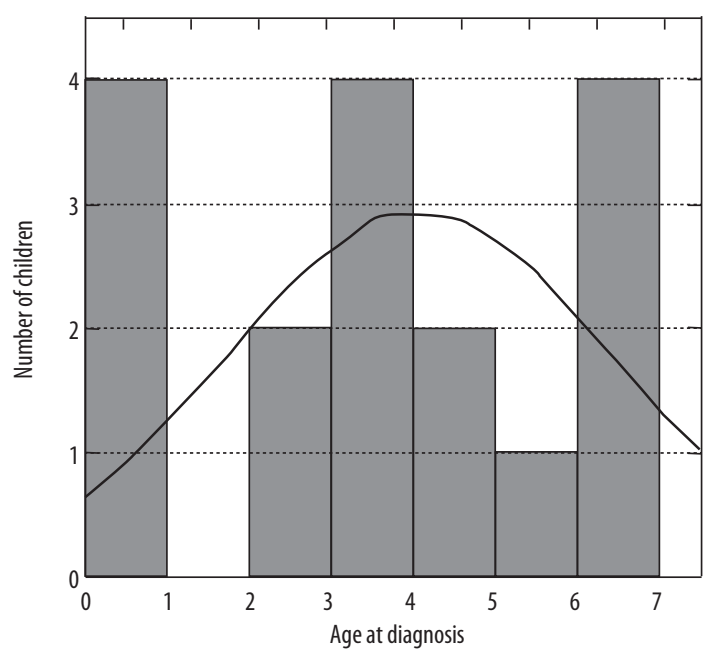

Figure 3. The average age at which hearing loss was diagnosed.

tests were performed using the Pruszewicz monosyllabic Polish word test [8]. Tests were conducted in quiet and also in noise at a signal-to-noise ratio of $+10 \mathrm{~dB}$. Before the operation, patients were tested with hearing aids. A second test took place 1 year after the operation, and a third 5 to 7 years after the operation. Subjects were tested using their natural bilateral acoustic hearing, amplified if needed with a hearing aid or a Duet acoustic component manufactured by Med-El, with electrically stimulated hearing occurring via the cochlear implant. Paired-sample $t$-tests were conducted to look for a difference in speech scores. The level of statistical significance $(p)$ was set at 0.05 .

The educational placement of the children was assessed with survey designed for the study and distributed to the parents.

\section{Results}

\section{Educational placement}

At the time of CI surgery, the children were mainly attending pre-primary or primary schools (78\%). Subsequently, they continued their education with no apparent interruptions. Figure 4 shows the shift to consecutive educational levels.

Prior to implantation, $89 \%$ of children were educated in mainstream schools and $11 \%$ were attending schools for the deaf and hard of hearing. After 5 to 7 years of implant use the percentage of children in mainstream setting was $83 \%$ and $17 \%$ were in special education. In the case of one child, one year after implantation he changed from a special school to a mainstream school and continues education in it. One child, who before the operation was in a special school for the hard of hearing, remains in it. In this case the type of school was chosen by the parents. Two children moved from a mainstream school to a special school when starting a new stage of their education (to a lower secondary general and an upper secondary vocational); at these higher levels the children could not manage in a mainstream school.

\section{Speech testing}

The results of monosyllable testing in quiet and in noise are presented in Figure 5, which show mean scores and standard deviations. For all children the post-implant scores after 1 year of CI use exceeded the pre-implant scores. Over a period of 12 months monosyllabic word recognition increased from 29 to $70 \%$ under quiet conditions and from 8 to $46 \%$ under noisy conditions. The results of speech tests in quiet were stable over time, as the recent mean score (5 to 7 years after surgery) was $70 \%$ as well. However, scores in noise improved over time to reach $65 \%$. These changes were statistically significant (at $p<0.05)$.

\section{Discussion}

The age distribution of children at the time of their implantation corresponds with their level of education (Figure 4). There is a visible increase in the number of PDT interventions at age 6 , when children enter school, with another peak at 10 to 12 when they are finishing primary education and moving to secondary school. Problems with coping with school requirements become more evident with time, the expectations towards children increase, and parents, dealing with multiple problems, start looking for a solution. According to parental reports, all children from the study group exhibited academic setbacks in the mainstream settings. The concern that the child would drop out from the current educational setting was mentioned by parents as one of the main reasons for deciding for a CI.

Before and after PDT, children were mainly enrolled in mainstream schools rather than in special education. The typical age at implantation in our sample was much higher than in regular pediatric CI cases, so it can be considered as 'late' implantation. Still, children's development in terms 


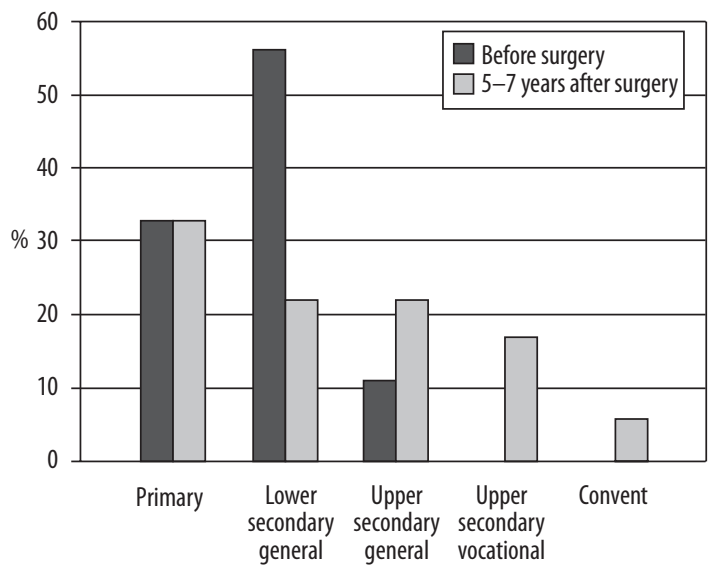

Figure 4. PDT students $(n=18)$ in the Polish education system before (black) and 5-7 years after surgery (grey).

of education level before implantation was only slightly hindered and nearly all children started education in a mainstream setting. Their capabilities fulfilled the criteria for acceptance into the primary open education system.

However, there is a reported tendency toward shifting from mainstream to special educational settings as the child grows older and academic demands and linguistic challenges become harder [9]. Some studies show that speech discrimination and language deficits present educational challenges in mainstreamed CI children [10]. Mukari et al. found that $56 \%$ of children with CI performed at below the average level on measures assessing school performance [6]. On the other hand, long-term data from the current study show a trend toward continuing mainstream education by children after PDT in the same way as their hearing peers. As there are no studies showing the educational status of children after PDT, we need to compare our data to results obtained in a group of hearing aid users.

As reported by Archbold et al. for severely deaf children, $38 \%$ of those using hearing aids attended full-time mainstream schools, compared to children after PDT where 83\%

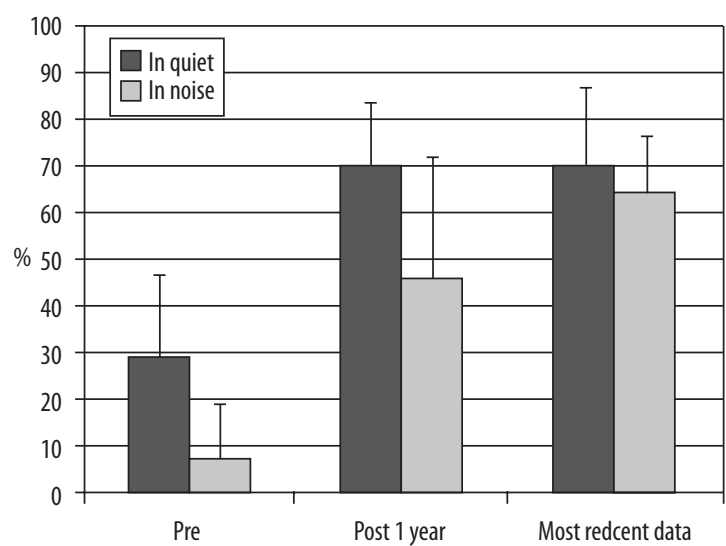

Figure 5. Speech perception before and after implantation. Monosyllable scores in quiet (black) and in noise (grey) before, one year, and 5-7 years after surgery.

attended regular school after a minimum of 5 years of CI use [11]. The goal of keeping children after PDT in mainstream education was supported by major improvements in their speech perception abilities, with their speech discrimination scores increasing by 41 percentage points on average. Considering the children's age at implantation (mean 9.9 years), and the observed saturation of speech perception at a low level (29\% mean monosyllabic test score) for long periods before implantation, this finding should be seen as a great success for CI implantation in PD children. We can assume that expectations surrounding implantation of children with PD have been satisfied, although more careful research on educational outcomes is needed.

\section{Conclusions}

Successful inclusion of hearing-impaired children in mainstream education is one of the main goals of cochlear implantation. Although the study group was small, it seems that PDT children, whose speech perception after cochlear implantation substantially improves, can continue their education in a mainstream setting.

\section{References:}

1. Skarzynski H, Lorens A, Piotrowska A: A new method of partial deafness treatment. Med Sci Monit, 2003; 9(4): CS20-24

2. Skarzynski H, Lorens A, Piotrowska A, Anderson I: Partial deafness cochlear implantation in children. Int J Pediatr Otorhinolaryngol, 2007; 71(9): 1407-13

3. Cole EB, Flexer C: Children with hearing loss developing listening and talking. Plural Publishing Inc., 2007; 185

4. Archbold S, Nikolopoulos T, Lutman M, O'Donoghue G: The educational settings of profoundly deaf children with cochlear implants compared with age-matched peers with hearing aids: implications for management. Int J Audiol, 2002; 41: 157-61

5. Skarzynski H, Lorens A: Electric acoustic stimulation in children. Adv Otorhinolaryngol, 2010; 67: 135-43

6. Mukari S, Ling L, Ghani H: Educational performance of pediatric cochlear implant recipients in mainstream classes. Int J Pediatr Otorhinolaryngol, 2007; 71: 231-40
7. Harrell RW: Pure tone evaluation. In: Handbook of Clinical Audiology, Katz J (ed.). Baltimore, Lippincott Williams \& Wilkins, 2002; 71-87

8. Pruszewicz A, Demenko G, Richter L, Wika T: New articulation lists for speech audiometry. Part II. Otolaryngol Pol, 1994; 48(1): 56-62

9. Yehudai N, Tzach N, Shpak T et al: Demographic factors influencing educational placement of the hearing-impaired child with a cochlear implant. Otology \& Neurotology, 2011; 32: 943-47

10. Geers A, Nicholas J, Sedey A: Language skills of children with early cochlear implantation, Ear Hear, 2003; 24(Suppl.): 46S-58S

11. Archbold S, Nikolopoulos T, Lutman M, O’Donoghue G: The educational settings of profoundly deaf children with cochlear implants compared with age-matched peers with hearing aids: implications for management. Int J Audiol, 2002; 41(3): 157-61 